University of Louisville

ThinkIR: The University of Louisville's Institutional Repository

Electronic Theses and Dissertations

$5-1912$

\title{
Atmospheric nitrous and nitric acids and their absorption by rain and surface water.
}

Alexander Y. Lee

University of Louisville

Follow this and additional works at: https://ir.library.louisville.edu/etd

\section{Recommended Citation}

Lee, Alexander Y., "Atmospheric nitrous and nitric acids and their absorption by rain and surface water." (1912). Electronic Theses and Dissertations. Paper 808.

https://doi.org/10.18297/etd/808

This Master's Thesis is brought to you for free and open access by ThinkIR: The University of Louisville's Institutional Repository. It has been accepted for inclusion in Electronic Theses and Dissertations by an authorized administrator of ThinkIR: The University of Louisville's Institutional Repository. This title appears here courtesy of the author, who has retained all other copyrights. For more information, please contact thinkir@louisville.edu. 
"ATIOSPHARIC IIITROUS AID IIITRIC ACIDS AID THETR ABSORPTION BY RAIIN AID SURTACE WATER."

$$
\text { A THESIS }
$$

SUBIITTAD TO THE FACUITY

$$
\text { of the }
$$

COLIEGE OF ARTS AID SCIPITCES

$$
\text { of the }
$$

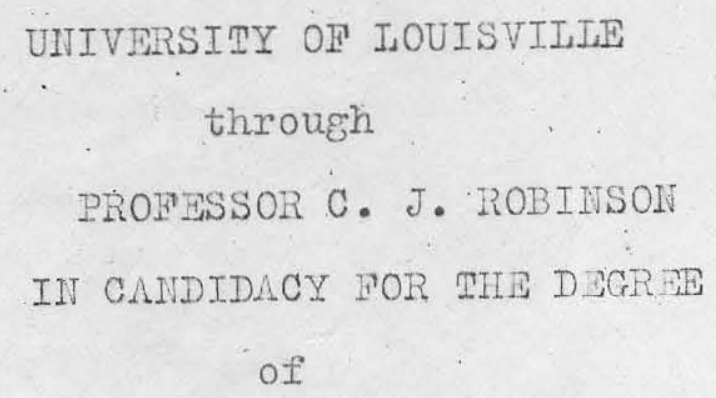

by

AIEXANDER Y. EIE

1912 


\section{(1)}

Atmospheric Nitrous and Nitric Acids and Their Absorption by Rain and surface Water.

Having been born and brought up in China, an empire, where the people are utterly ignorant of the vital importance of a good system of public water supply, and having decided to take chemistry as my profession, I feel intensely interested in the examination of water for the purpose of convincing our people in the far east to pay proper attention to sanitation on a chemical basis. The average life period there has been roughly estimated to be thirty years, and we have now in the Middle Kingdom a population of 450000000 . It means in each century we have approximately 1000000000 of pe ple there to drink water, not a drop of which has ever been examined to ascertaining whether is free from germs that cause dangerous diseases. In every Summer there break out disastrous epidemics of cholera which frequently result from the use of polluted water, and the people attribute such periodic calamities to the mischief of evil spirits. Persons with typhoid fever, which is also scattered by contaminated waters, are shut up in small rooms with windows and doors closed, thinking cold air to be the ultimate cause of such a malady. By experience they found out that the habit of using cold drinks would injure their health, and thus their favorite beverage has for a few thousands of years been a cup of hot tea. Being ignorant of the baneful consequences, they wash their rice and clothes in the same pond five feet apart. Turbidity, or suspended matters is the only thing that looks offensive to them, and consequently centuries ago they discovered the peculiar property 
of alum for. coagulation, and the latter substance has bean extensively manufactured in China for the purpose of purlfying their drinking water. Alum, as a good agent for coagulation, has been the chief domestic drug in the Chinese homes, for to any persion who is selzed abruptly with a serious disease is invariably given a lump of this substance dissolved in a cup of hot water, thinking that the constituents of the sickness in the patient's stomach could be coagulated. Consequently no Chinese home is without a box of alum kept in readiness for emergencies, and large lumps of it are thrown into the water tank when the turbidity of river water is great. Those whose residences are not situated in the vicinity of any stream use water drawn from wells.

Shortly after I entered the University of Louisville, I considered myself exceedingly fortunate in obtaining an opportunity of working in the water plant of the city. Having worked for a few months with those who carry out their daily routine of analysis in the laboratory, I began to take such interest in the work that I wished I could write my thesis on some phase of the work at the suggestion of Prof. Bobinson. My attention was directed to the occurence of nitrites and nitrates in nature waters and rain water, and the fact that the absorption of these substances from the air has not received a great deal of attention from chemists. these seemed also to be a possibility that the presence of these substnces in some surface waters might be entirely accounted for by such absorption from the air. Chenists generally assert that these substanc occur in water because of oxidation of organic matter with which 
the water has become contaminated.

Historical- Very little has been done in the determination quantitatively of both nitrites and nitrates in natural waters aside from two or three cases in which some general statement of the existance of these two substances in rain water is made with rer ference to specific localities whthout giving any clear origin from which these substances could be procured. In Sir H. E. Roscoe's Treatise on Chemistry, concerning the subject, the following statements are given.

"The average amount of nitrogen contained in country rain water as ammonia, organic nitrogen, nitrous and nitric acids is about .7 parts per million, whilst the rain of London (Hyde Park) contains 2.2 parts per million"

Roussinga-ult, on the other hand, found in the rain of Paris 4 parts of ammonia in one million, and nitric acid .2 in a million. Dr. Edward Bartow, Director of State Water Survey of Illinois, gives the following suggestion.

"In our interpretation of results, we take into consideration the fact that nitrites may occur in well waters containing iron because of the reduction of nitrates by means of ferrous salts. It would be very interesting if you (Prof. Robinson) can show that nitrites in water, otherwise pure, may be present because of absorption from the air. It would seem to me that the amount would be small because of the almost immediate oxidation of the nitrites to nitrates by means of the dissolved oxygen present. If something could be added to the water which could prevent this oxidation, the nitrite content might 
possibily be increased. The nitrite content in pure river and lake water is usually very low. If nitrites are present in quantity, they are usually accompanied by other indications of contamination such as albuminoid ammonia, high oxygen consuming power, high bacterial content and the presence of gas former". In the Annual Report of the State Agricultural College of Kansas for the year 1889, Prof. J. T. Willard gave the results of the analysis of nitrites and nitrates in the rain water of the four previous years. It is stated that the notrogenous compounds in the rain waters were then analyzed under two divisions. In any sample nitrogen as ammonia was first tested, and then all the nitrites and nitrates were reduced to the fomr of ammonia, which was again tested, and the difference of these two determinations was attributed to nitrates. This explained why no nitrites were mentioned in the rain waters in former times. However in the year 1887 Prof. Willard did make quatitative quaIitative nitrite determinations in the rain waters, and his results are quoted as follows.

"In the time mentioned"-from May 1887, to September 1889-"one hundred and seventy-one rains were tested for nitrites. Of these one hundred and twenty-eight gave the reaction for nitrites without concentration; twenty-nine gave no reaction and fourteen were doubtful. There were one hundred and thirty-two rainsin the six months from April to September, inclusive. Nitrites were presentin 86 per cent, of these, and absent or doubtful 14 per cent. There were thirty-nine rains in the remaining six months, October to March, inclusive. In 36 per cent. of these nitrites were present and in 64 

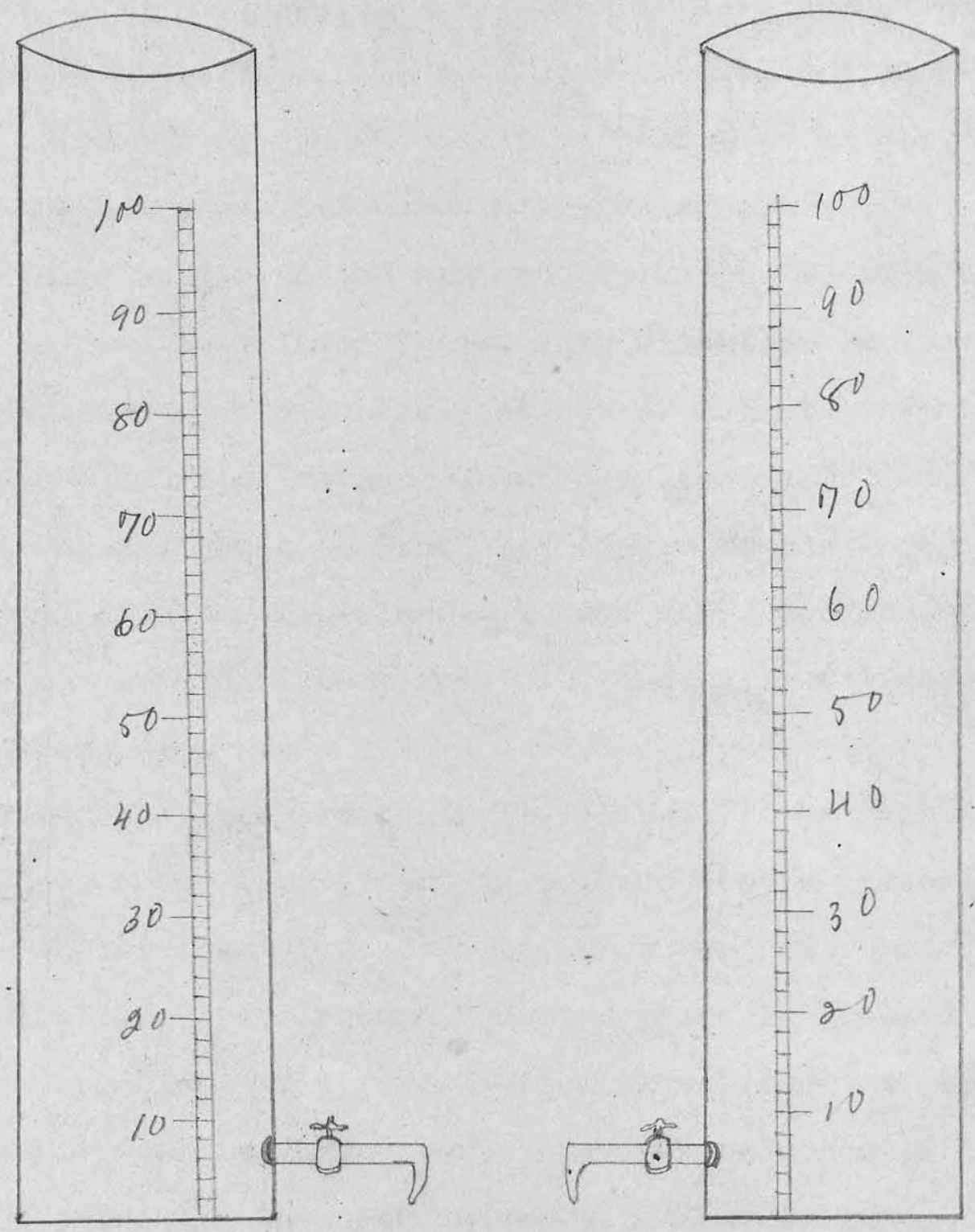
per cent., absent or doubtful." The result of these four years determinations is atated as follows.

Mean rainfall for four years........29.14 inches

Nitrogen in $\mathrm{NO}_{2} \& \mathrm{NO}_{3} \ldots \ldots \ldots \ldots \ldots \ldots . . . . .66$ pounds per acre

Nitrogen in ammonia.............2.63 pounds per acre

From the preceeding quotations it is seen that chemists seem to agree that there are traces of nitrates in natural waters that have their origin in the atmosphere, but as to nitrites, they seem to have been investigated very slightly. In Roussingault's conclusion he stated the presence of nitrate and ammonia. in rain water, but said nothing about nitrites, and I have no way of getting his paper to find out detalis of his experiments. So far as concerns the experiments I have made, conclusions to be drawn are some what different from his, and will be treated a little later.

Fresh natural waters are generally classified as rain water, surface water, subsoll or ground water, and deep or artesian water. Water in any form of dew, frost, snow, or hail that finds its contaminations only through the atmosphere is grouped in the first class. portions of watercollected in various low places-rivers, or small streams, lakes, or ponds-in free contact with the atmosphere belong to the second class. Fortions of water percolating through soil or rock at moderate distances below the surface and not in free contact with the atmosphere are called subsoli water under the third class. Portions of water accumulated at great depths below the surface are named deep water under the 
fourth class. With reference to the amount of nitrites and nitrates contained in each class, I find a table in "Examination of Water", by Leffman, as follows. In the following table the numbers designate parts per miliion.

Kain Surface Subsoil Deep

Nitrogen

in traces or none .03 to none .03 to none traces or none Nitrites

Nitrogen
in
traces
.75 to 1.251 .5 to 5.0
none to 3.0

Nitrates

The preceding data will be discussed again. In regard to the origin ofthese two nitrogenous compounds existing in the natural waters, I find, in Leffmann's "Water Examination" the following remarks.

Nitrites are present in water as the result either of incomplete nitrification of ammonia, or the reduction of already formed nitrates under the influence of reducing agents or microbes. Hitrates are the final point in the oxidation of nitrogenous organic matter, espectially animal matter." Quoting Roscoe and Shorlemmer's "Treatise on Chemistry": "If water be impregnated with animal matter, this will be indicated by the presence of nitrogen in solution, either in the form of albumin or albuminous matter, if the animal matter be contained in the water unchanged, or, if the animal matter has undergone oxidation, in the form of ammonia, or nitrous or nitric acid."

We can safely agree with the above-mentioned authors that at least part of the nitrites and nitrates present in water is derived from the animal matters. But the question here arises: 
'What per centage of these two substances in water can be attributed to animal matter? In other words, does the atmosphere contribute some nitrates and nitrites to the water? A satisfactory answer to this question does not seem to be found in any chemistry or in any water analysis, and apparently this problem has never been solved. In order to find a solution for this problem, it is necessary to seek for experimental froofs, for with speculation alone, a person could never accomplish this task even throgh he had a Greek mind. It is, therefore, my task to devise methods by mears of which I may be able to interpret the answer which the silent natuee gives only to experiments.

Before entering into discussions of the apparatus and my experimental results, I wish to describe the methods with which I test my nitrates and nitrites. All my determinations of these two radicals are made in accordance with the directions given by Leffmann in the book entitled "Examination of Water for Sanitary and Technic Purposes." The method with which to determine nitrates is devised by A. H. Gill. It is volumetric and the estimation of minute quantities of the substance is very effective and accurate.

"Solution Required:

Phenoldisulphonic Acid Sulfuric Acid $\ldots \ldots \ldots \ldots \ldots \ldots \ldots \ldots \ldots \ldots \ldots \ldots \ldots \ldots \ldots$ grams Phenol.......................... 9 grams

The mixture is heated for six hours in the water bath. The resulting compound often solidfies to a white mass on stianding, but can be easily liquefied on the water bath during the evapora- 
tion of the samples to be tested.

Standard potassium nitrate ( 0.722 gram of potassium nitrate), previously heated to a temperature just. sufficient to fuse it, dissolved in water, and the solution made up to $1000 \mathrm{c.c}$. One c.c. of this solution will contain 0.0001 gram of nitrogen.

\section{Analytic Process:}

A measured volume of the water is evaporated just to dryness in a porcelain basin about six centimeters in diameter. One c.c. of the phenoldisulphonic acid is added and throughly mixed with the resdue by means of a glass rod. The liquid is then diluted with about $25 \mathrm{c.c}$. of water, ammonium hydroxide added in excess, and the solution made up to $50 \mathrm{c} . \mathrm{c}$.

One c.c. of the standard solution of potassium nitrate is now similarly evaporated in another basin, treated as above, and made up to $50 \mathrm{c.c}$. The color produced is compared to that given by the water, and one or the other of the solutions is diluted until the tints of the two agree. The comparative volumes of the liquids furnish the necessary data for determining the amount of nitrates."

Picric acid is formed by reaction of phnoldisulphonic acld$\mathrm{C}_{6} \mathrm{H}_{5} \mathrm{OH}\left(\mathrm{HSO}_{3}\right)_{2}$ with nitrates in whatsoever form. By adding to a sample of water containing nitrates phenoldisulphonic acid, we, therefore, have picric acid produced; and on addigymonium hydroxide these results potassium picrate, which imparts to the solvent a yellow color, the intensity of which is directly proportional to the amount present. The amount of nitrates in the sample is estimated by comparing the color of the sample with that of the 
standard solution. The reactions taking place during this process can be represented by the following equqtions.

$\mathrm{C}_{6} \mathrm{H}_{5} \mathrm{OH}+2 \mathrm{H}_{2} \mathrm{SO}_{4} \rightarrow \mathrm{C}_{6} \mathrm{H}_{3} \mathrm{OH}\left(\mathrm{HSO}_{3}\right)_{2}+2 \mathrm{H}_{2} \mathrm{O}$

$\mathrm{C}_{6} \mathrm{H}_{3} \mathrm{OH}\left(\mathrm{HSO}_{3}\right)_{2}+3 \mathrm{HNO}_{3} \rightarrow \mathrm{C}_{6} \mathrm{H}_{2}\left(\mathrm{NO}_{2}\right)_{3} \mathrm{OH}+2 \mathrm{H}_{2} \mathrm{SO}_{4}+\mathrm{H}_{2} \mathrm{O}$

$\mathrm{C}_{6} \mathrm{H}_{3}\left(\mathrm{NO}_{2}\right)_{3} \mathrm{OH}+\mathrm{NH}_{4} \mathrm{OH} \rightarrow \mathrm{C}_{6} \mathrm{H}_{2}\left(\mathrm{NO}_{2} \mathrm{ONNH}_{3}+\mathrm{H}_{2} \mathrm{O}\right.$

The method for the determination of nitrites in water is Ilosvay's modification of Griess's test. The direction of the analysis is

as follows.

"Solutions Required:

I-4-Amidobenzenesulfonic Acid Solution (Sulfanilic Acid) -0.5 gram dissolved in $150 \mathrm{c.c}$. of diluted acetic acid, sp. gr. 1.04

Alpha-Amidonaphthalene Acetate Solution.

Standard Sodium Nitrite-One c.c. of which contains 0.00001 gram. of nitrogen.

\section{Analytic Process:}

Twenty-five c.c. of the water are placed in one of the color comparison cylinders, and two c.c. of each of the test solutions are dropped in. It is convenient to have pipet for each solution, and to use it for no other purpose.

One $c, c$. of the standard nitrite solution is placed in another clean cylinder, made up with nitrite-free water to $25 \mathrm{c.c}$,, and treated with the reagents as above. In the presence of nitrites the liquid becomes pink. At the end of five minutes the two solutions are compared, the color equalized by diluting the darker, and the calculation made as explained under the estimation of nitrates."

In the preceeding test the estimation is based upon the pink 
color produced in the water by azo-alnha-aminonaphthalene-1-4benzenesulphonic acid $\left(\mathrm{C}_{6} \mathrm{H}_{4} \mathrm{HSO}_{3} \mathrm{~N}_{2} \mathrm{C}_{10} \mathrm{H}_{6} \mathrm{NH}_{2}\right)$. The density of the color is also proportional to the amount of nitrites present. The reaction consists in the conversion of the sulfanilic acid$\mathrm{C}_{6} \mathrm{H}_{4} \mathrm{NH}_{2} \mathrm{HSO}_{3}$-into diazobenzenesulphonic anhydride- $\mathrm{C}_{6} \mathrm{H}_{4} \mathrm{~N}_{2} \mathrm{SO}_{3}-\mathrm{by}$ the nitrite present. This substance is then in turn converted, by aminonaphthalene $-\mathrm{Go}_{7} \mathrm{NH}_{2}$-into azo-alpha-aminonaphthalene-l-4benzenesulphonic acid. The following equations represent the changes.

$$
\begin{aligned}
& \mathrm{C}_{6} \mathrm{H}_{4} \mathrm{NH}_{2} \mathrm{HSO}_{3}+\mathrm{HNO}_{2} \rightarrow \mathrm{C}_{6} \mathrm{H}_{4} \mathrm{~N}_{2} \mathrm{SO}_{3}+2 \mathrm{H}_{2} \mathrm{O} \\
& \mathrm{C}_{6} \mathrm{H}_{4} \mathrm{~N}_{2} \mathrm{SO}_{3}+\mathrm{C}_{10} \mathrm{H}_{7} \mathrm{NH}_{2} \longrightarrow \mathrm{C}_{6} \mathrm{H}_{4} \mathrm{HSO}_{3} \mathrm{C}_{10} \mathrm{H}_{7} \mathrm{NH}_{2}
\end{aligned}
$$

In addition to the chemical changes, I wish to explain my modification of the test in regard to time. The customary procedure is the use of stanardized solution of sodium nitrite with 0.00001 gram of nitrogen as the smallest unit, and at the end of five minutes the colors should be equalized. By experience I found that in water an amount of nitrites less than 0.03 part per million would be overlooked by applying a limit of five minutes for its development. Theoretically the pink color depends upon the existence of azo-alpha-aminonaphthalene-1-4-benzenesulphonic acid, and to a sample of water, containing no nutrites on adding the reagents, no diazobenzenesulphonic anhydrid could be formed. The absence of the latter means the impossibility of forming azo-alpha-aminonaphthalene-1-4-benzenesulfonic acid, and the same sample could be kept in an enclosed bottle for ever with these two reagents and yet without pink color. And this theory was checked by experiments, for I placed $100 \mathrm{c.c}$. of distilled 
(11)

nitrite-free water in one of the color-comparision cylinders with the usual reagents and kept it closed for two days and found no pink color. Consequently the limit of five minutes is only an arbitary time to hasten the test. For technical purposes a moderate accuracy of estimation is only required, hence the limit of five so minutes. However for research work time is not much emphasized as accuracy, and it would be advisable to remove the limit of five minutes. Often times I had to use sodium nitrite solution with the strength of 0.000001 gram nitrogen in one c.c. and allow 30 , or 40 , or sometimes an hour for its development. The cylinders were always kept closed during this time by corks.

Hehner's cylinders ( $f$ ig 1 ) are used for the tests, and the results are recorded in terms of parts per million.

In our attempts to throw some light on the question of the extent of absorption of nitrous and nitric acids from the atmosphere, experiments along three lines have been carried out as follows.

(1) Determination of the amount of nitrites and nitrates in the atmosphere.

(2) Determination of the amount of nitrites and nitrates in rain water.

(3) Determination of the rate of absorption of the nitrites and nitrates of the atmosphere by water

(1) Nitrites and nitrates inthe atmosphere:

The apparatus which I devised for the purpose of measuring directIy the amount of nitrites and nitrates in the atmosphere is represented in fig $A$. FI? $M N$, and $P Q$ are three bottles, each of 
which has a capacity of 500 c.c. In $P Q$ I placed 200 c.c. of distilled water containing 0.1122 gram of calcium bicarbonat, and in FI 200 c.c. of distilled water with twice as much calcium carbicarbonate as in the bottle $\mathrm{MN}$, but in $\mathrm{PQ} I$ placed 200 c.c. of distilled water without any calcium salt. They are well closed by rubber corks and connected in series by glass tubes as indicated in the figure. RUV is a long piece of glass tubing one end of which is connected with the bottle $P Q$, and the other end passes through the window and extends out in the open air above the roof. HED is another piece of glass tubing connecting the small bottle FI with the large bottle $A B$ which has a capacity of about 20 liters. WX is another piece of glass tubing connected with a piece of rubber tubing XY, a piece of large glass tubing $Y Z$, another piece piece of rubber tubing $\mathrm{Zd}$, and finnally another piece of small glass tubing ds...chab is a stand upon the holder ch of which is attached by means of wire an empty glass sphere with a wide opening at $k$, and a small outlet at $g$. When the large bottle $A B$ is filled with water up to a mark $\mathrm{k}$ which indicates a fixed volume found by measurement to be $18500 \mathrm{c.c}$. The filling of water is done by attaching the glass tubing ds to a water faucet, and open the rubber cork $r$, and when the bottle is filled up to the mark 1 , the water is turned off and the cork $r$ is replaced. Then the glass twhigrig tubing $d s$ is disconnected from the faucet, and the water in the bottle $A B$ begins to siphon out. Immediately the jet of water is indroduced into the glass sphere through the mouth $\mathrm{k}$, and the portion of rubber tubing is placed across the holder ch of the 

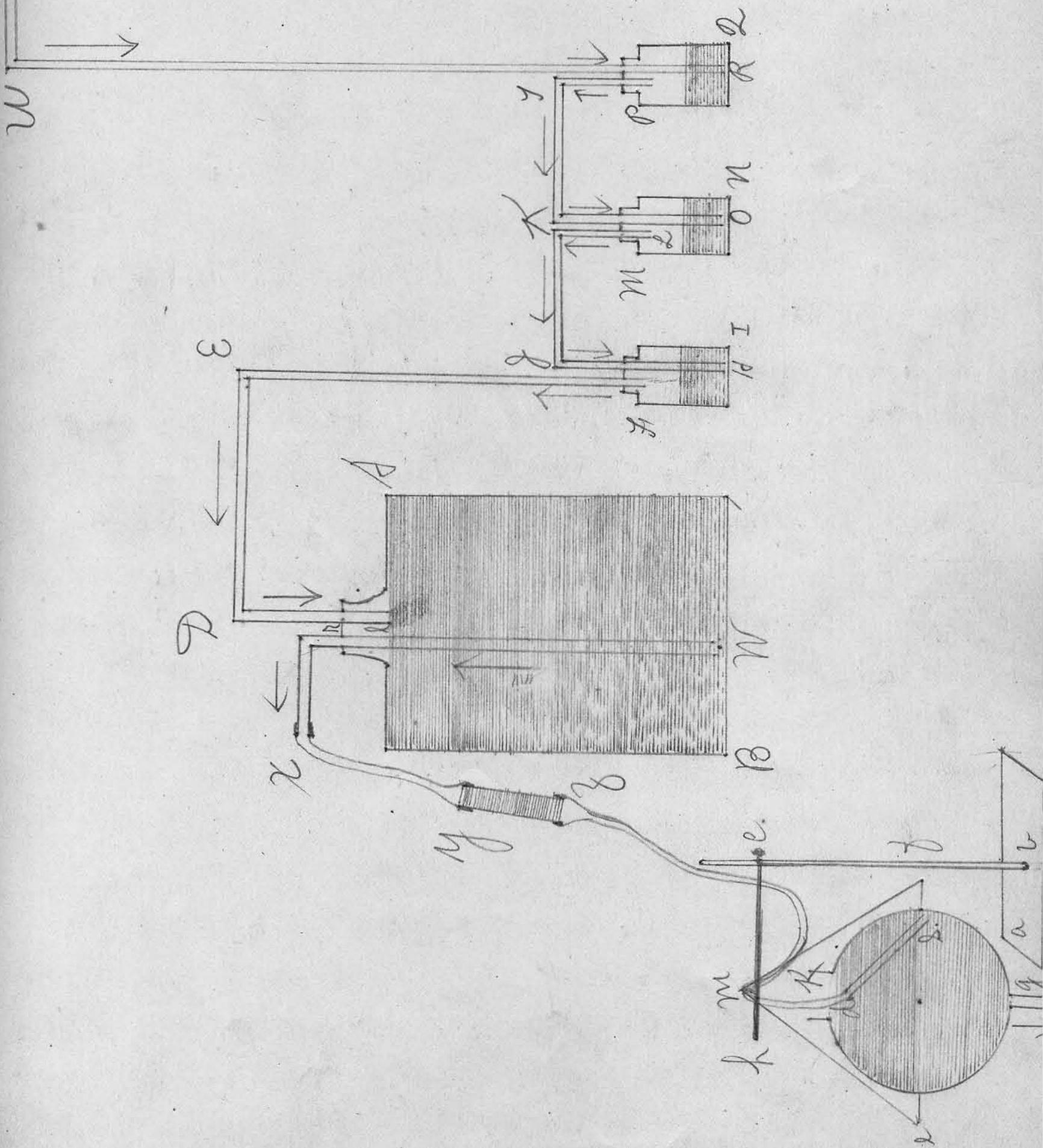
No. of

Experiments

$\begin{array}{ll}1 & \mathrm{~N} \text { as } \mathrm{NO}_{2} \\ 1 & \mathrm{~N} \text { as } \mathrm{NQ}_{3} \\ 2 & \mathrm{~N} \text { as } \mathrm{NO}_{2} \\ 2 & \mathrm{~N} \text { as } \mathrm{NO}_{3}\end{array}$

$\begin{array}{ll}3 & \mathrm{~N} \text { as } \mathrm{NO}_{2} \\ 3 & \mathrm{~N} \text { as } \mathrm{NO}_{3}\end{array}$

$4 \quad \mathrm{~N}$ as $\mathrm{NO}_{2}$

4

5

5

6

6

7

7

8

8

9

9

10

10

11

11

12

12

13

13
Volumes of

Air (Liters)

18.5

18.5 .

37.0

37.0

55.0

55.0

74.0

74.0

92.5

92.5

195.0

195.0

390.0

390.0

585.0

585.0

1000.0

1000.0

693.0

693.0

740.0

740.0

925.0

925.0

2000.0

2000.0
Temperature $\not^{\circ}$

$?$
$?$
$?$
$?$
$?$

20-30

$20-30$

$10-30$

$10-30$

$10-40$

$10-40$

$10-60$

$10-60$

$16-60$

$16-60$

20-60

20-60

50-77

$50-77$

70

70

$60-70$

$60-70$

$50-80$

$50-80$ 
(14)

\begin{tabular}{|c|c|c|c|}
\hline $\begin{array}{l}\text { parts per million } \\
\text { in Bottle } P Q \text {. }\end{array}$ & $\begin{array}{l}\mathrm{p} \cdot \mathrm{p} \cdot \mathrm{m} \text {. } \\
\text { in } \mathrm{MN}\end{array}$ & $\begin{array}{l}\text { Milligrams of } \mathrm{N} \\
\text { as } \mathrm{NO}_{2} \& \mathrm{NO}_{3} \text { abs. }\end{array}$ & $\begin{array}{l}\text { Milligra } \\
\text { as NQ \& } \\
1000 \text { 11t }\end{array}$ \\
\hline $\begin{array}{l}\text { none } \\
\text { none }\end{array}$ & none & & \\
\hline none & none & & \\
\hline none & none & & \\
\hline none & none & & \\
\hline none & none & & \\
\hline none & none & & \\
\hline trace & none & & \\
\hline none & none & & \\
\hline trace & none & & \\
\hline none & none & & \\
\hline tradee & none & & \\
\hline none & none & & \\
\hline 0.03 & none & 0.006 & 0.0165 \\
\hline none & none & & \\
\hline 0.03 & none & 0.006 & 0.0110 \\
\hline none & none & & \\
\hline 0.12 & trace & 0.024 & 0.0240 \\
\hline trace & none. & & \\
\hline 0.09 & none & 0.018 & 0.8252 \\
\hline trace & none & & \\
\hline trace & none & - & \\
\hline none & none & & \\
\hline $\begin{array}{l}0.10 \\
\operatorname{trace}\end{array}$ & b none & 0.020 & 0.0238 \\
\hline trace & none & & \\
\hline $\begin{array}{l}0.28 \\
0.05\end{array}$ & $\begin{array}{l}\text { trace } \\
\text { none }\end{array}$ & 0.066 & $\$ .086$ \\
\hline
\end{tabular}


stand, and twine which suspends the glass sphere is placed across the rubber tubing at $m$. At first the water becouse of'its high pressure siphons out very rapidly, and there is more water running out from $s$ into the glass sphere than its outlet $\mathrm{g}$ could let out, and as a consequence of this condition, the water in the sphere is accumulating all the time. The more water accumulates in the sphere, the heavjer the sphere becomes, and the weight of the sphere which bears on the rubber tubing $\mathrm{m}$ tends to choke the water from running out of the bottle $A B$ at $m$. Consequently an equilibrium is established which serves as a regulator to give a constant flow, so that the stream of air passing through the small bottles shall be constant, in order to insure perfect absorption of nitrites and nitrates. As soon as the first bottle of water is siphoned out, I remove the glass tube from the glass sphere, and attach it again to the faucet, and lat the water run in the bottle $A b B$ very slowly till the water in the bottle FI begins to rise in the tube HJ, for there is a partial vachum in the bottle $A B$. As soon as the partial vacuum is filled with water, I turn off the faucet and open the cork $r$, and fill the bottle $A B$ with water from a graduated cylinder up to the mark I. Thus the volume of air which is forced in from $V$ through these three bottles into the large bottle is known (18500 c.c.). By repeating the same process one is able to draw over a volume of air as large as one pleases, and when the volume passes through PQ3 MN, and FI, the nitrites and nitrates are all absorbed in the water contained in the bottle $P Q$. Occasionlyy I found a trace of nitrites in MN, but none 
in FI, and no nitrates in either MiN or FI. The results of my experiments are given in the page (13) and 114).

In order to test or determine the rate at which the nitrites would be oxidized into nitrates by the oxfgen dissolved in water, I placed in the bottle MN 100 c.c. of sodium nitrite solution with the strength of 0.1 part nitrogen per milison, $200 \mathrm{c.c}$. of $h$ hard water in $P Q$, and $200 \mathrm{c} . c$. of hard water in FI. The $n$ I drew a certain volume of air through these bottles by siphoning the water out in $A B$ as I did before. The small amount of nitrites and nitrates in the atmosphere is absorbed in the bottle $P Q$, and if there should be any nitrite that is sucked over, it is held in the bottle FI. Having thus drawn over a volume of air, 92.5 , liters, through these three bottles, I found that theee was not a trace of nitrite in the bottle $\mathrm{MN}$ oxidized into nitrate. Then I repeated the experiment by drawning over a volume of air, 195 liters, I found there was but a trace of nitrate present in MN. (2) Nitrites and nitrates in rain water.

Rain water in different showers is collected in different clean beakers that are set out on a certain roof. Water caught in the first six hours is designated "During the first 6 hour", and water caught in the next six hours "During. the second 6 hours". etc. As a matter of fact there was no rain continued over two, or three days, but a period of five, or six dayswithout sunshine, and rain now and then, is designated as "During the ist day, During the and day etc" 
The sesults of my experiments are as follows;

Experiment p.p.m. of $\mathrm{N}$ as $\mathrm{NO}_{2} \quad p_{0}$ p.m. of $\mathrm{N}$ as $\mathrm{NO}_{3}$ in rain in rain

1

3

4

$\begin{array}{ll} & 0.08 \\ & 0.05 \\ 5 & \text { trace } \\ 6 & 0.18 \\ & 0.20\end{array}$

0.01

0.10

0.12

O. Q1

0.16

.08 trace

none

$\operatorname{trace}$

trace

trace

trace

0.01

trace

none

0.05

0.04
During the 1st 6 hours

During the and 6 hours

During the 3rd 6 hours

During the 1st 6

D hours

During the 1st 6 hours

During the 2nd 6 hours

During the 3rd 6 hours

During the 2nd day in rain

During the 3 rd day

During the 6 th day

- During the lst 2 hours

During the 2nd two hours

During the 3rd 2 hours

During the 6 th 2 hours

During the 1st 2 hours

0.14
Thunder storm

Snow is gathered from the surface of the ground, and the time is recorded like that given in the rain. .

Experiment $p_{\bullet} p_{0} m_{0}$ of $\mathrm{N}$ as $\mathrm{NO}_{2} \quad p_{\bullet} p_{\bullet} \mathrm{m}_{\text {: }}$ of $\mathrm{N}$ as $\mathrm{NO}_{3}$ in snow in snow

1

0.05

none

During the lst 6 houss

trace

none

During the 2nd 6 hours 


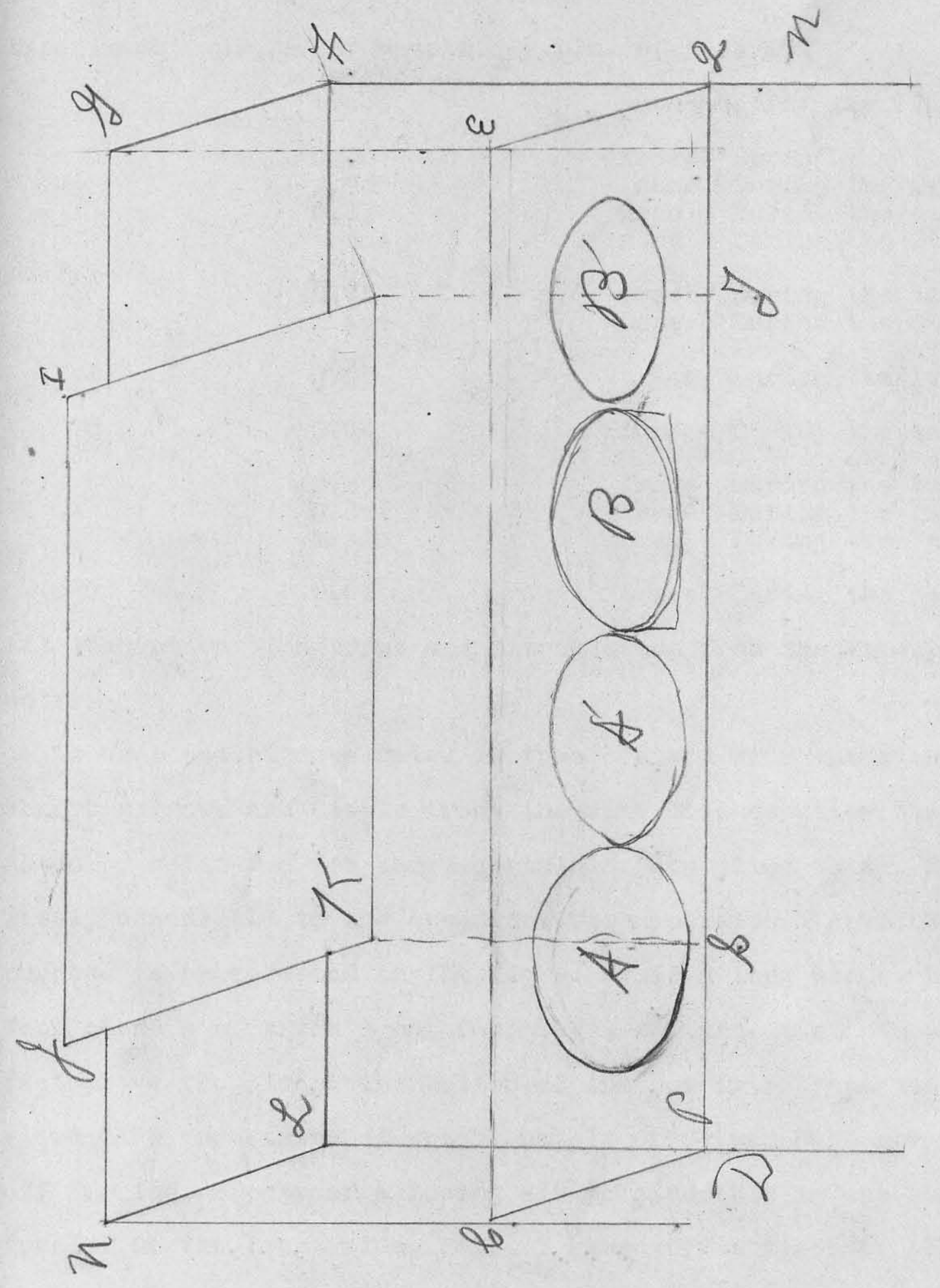


Experiment p.p.m. of $\mathrm{N}$ as $\mathrm{NO}_{2} \mathrm{p} \cdot \mathrm{p} \cdot \mathrm{m} \cdot \mathrm{i}$ of $\mathrm{N}$ as $\mathrm{NO}_{3}$
in snow snow

1

2

$$
4
$$

5

6

$0.04 ?$
trace
$7 \quad 0.05$

none During the 3rd 6 hours

trace? During the Ist 4 hours none During the 2 nd 4 ,hours none During the 4 th 4 hours none During the 7 th 4 hours

trace During the 1st 6 hours none During the and 6 hours

trace During the lst 4 hours none During the lst 6 hours

Trace During the lst two h trace During the and 2 hours none During the 7 th 2 hours

trace During the Ist 6 hours

(3) Absorption of nitreas and nitric acids from the atmosphere by water

To what extent does water in free contact with the atmosphere absorb nitrous and nitric frome the air? This question was investig gated by setting a few pans, containing distilled water, in a place freely accessible to the open air. The apparatus I devised for such purpose is represented in the $\mathrm{fig} b$. $\mathbb{M N}$ is a long wooden box at the four corners of which I put four legs, so that it stands about three feet above the floor. The bottom of the box is represented by the plane CEND two strips of which, namely CEPO, and RQND are sawed off for the purpose of allowing air to circulate in the box very freely. On the front side, FNDL, I sawed off a piece of board represented by SKHT, and the same is attached on the box at KH by means of two hings. SKHT is, therefore, used as a door, and 
when it isiopen, it takes the position IJKH. Four pans represented by $A$ ? $A^{\prime}, B$ and $B^{\prime}$ are placed in the box as in the figure $b$. They are thus protected from rain, and in part from dust; but in the cou course of 15 days, they invariably accumulated enough dust and soot from the city air to make replacement of the water in them advisable Whenever the water becomes very dirty before 15 days, it is filtered Box and pans were placed on a roof about thirty feet from the ground level. The open surface of each of the pans is 29.84 square inches. $A$ and $A^{\prime}$ contain 400 c.c. of distilled water; $B$ and $B^{\prime}$ contain 400 c.c. of distilled water with three perscent of calcium bicarbonate. Every three days $50 \mathrm{c.c}$. of the water in each pan was drawn out to test for nitrites and nitrates, and $50 \mathrm{c.c}$. of these two kinds of solvent were replaced in each pan accordingly. The results are given as follows. 
Nitrogen as Nitrites

(A)

$\begin{array}{lllll}\text { days p.p.m. } & \begin{array}{l}\text { p.p.m. } \\ \text { taken } \\ \text { out each } \\ \text { time. }\end{array} & \begin{array}{l}\text { acture } \\ \text { n.m. }\end{array} & \begin{array}{l}\text { acture } \\ \text { amount } \\ \text { in } 400 \\ \text { c.c. }\end{array} \\ 3 & \text { none } & \begin{array}{l}\text { none } \\ \text { none }\end{array} & \text { none } \\ 6 & .017 & .002 & .017 & .0058 \\ 9 & .033 & .004 & .035 & .0140 \\ 12 & .048 & .006 & .054 & .0216 \\ 15 & 0063 & & .075 & .0300\end{array}$

weather conditions

raining and cold Cloudy and cold bright and cold bright and warm bright and warm

Nitrogen as Nitrites in $\left(\mathbb{A}^{3}\right)$

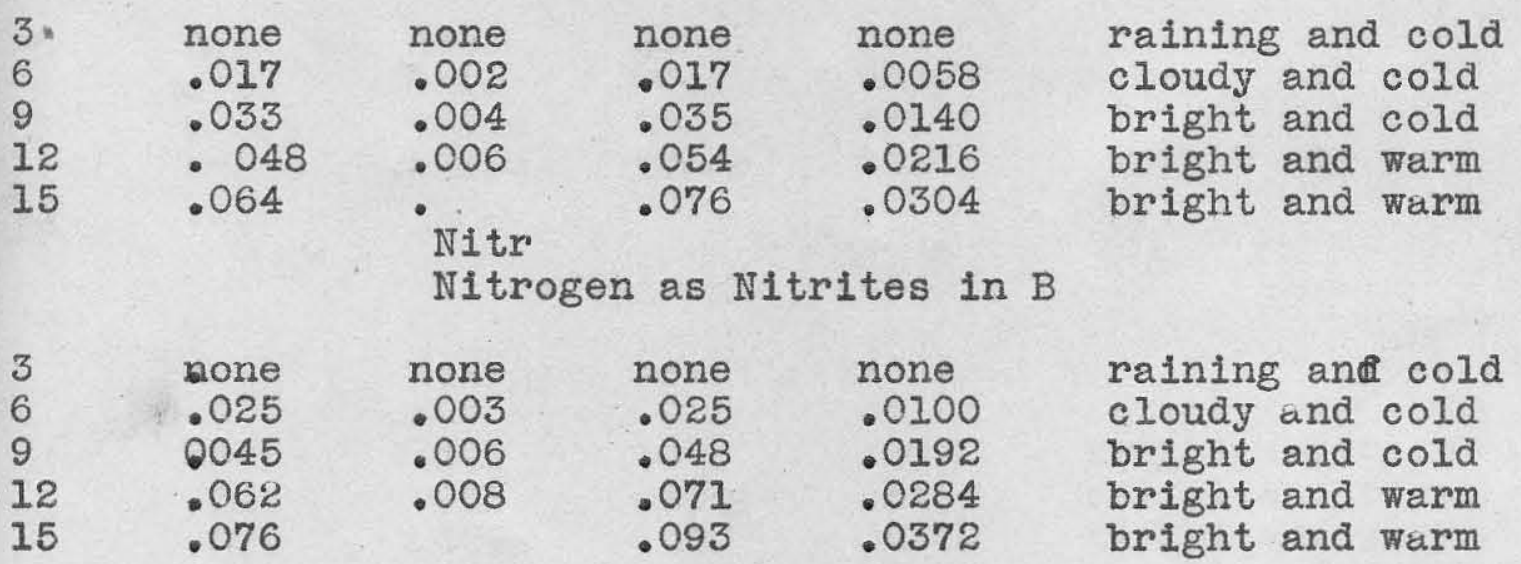

Nitrogen as Nitrites in $B^{\prime}$

$\begin{array}{ll}3 & \text { none } \\ 6 & .025 \\ 9 & .045 \\ 12 & .062 \\ 15 & .076\end{array}$

$\begin{array}{lll}\text { none } & \text { none } & \text { none } \\ .003 & .025 & .0100 \\ .006 & .048 & .0192 \\ .008 & .071 & .0284 \\ & .093 & .0372\end{array}$

raining and cold cloudy and cold bright and cold bright and warm bright and warm

Nitrogen as Nitrates in $\mathrm{A}$

none

none trace?

none

none

none

none

none

none

trace?

trace?

trace?

trace trace

trace

trace

.01

.01

.0040

Nitrogen as Nitrates in $A^{\prime}$

$\begin{array}{llllll}3 & \text { none } & \text { none } & \text { none } & \text { none } & \text { raining and cold } \\ 6 & \text { none } & \text { none } & \text { none } & \text { none } & \text { cloudy and cold } \\ 9 & \text { trace? } & \text { trace? } & \text { trace? } & \text { trace? } & \text { bright and cold } \\ \text { 12 } & \text { trace } & \text { trace } & \text { trace } & \text { trace } & \text { bright and warm } \\ 15 & .01 & & .01 & .0040 & \text { bright and warm }\end{array}$


Nitrogen as Nitrates in $B$

\begin{tabular}{|c|c|c|c|c|}
\hline$p_{0} p_{0} m_{0}$ & $\begin{array}{l}\text { p.p.m. } \\
\text { taken } \\
\text { out each } \\
\text { time }\end{array}$ & $\begin{array}{l}\text { acture } \\
p \cdot p \cdot m\end{array}$ & $\begin{array}{l}\text { acture } \\
\text { amount } \\
\text { in } 400 \\
\text { c.c. }\end{array}$ & weather condition \\
\hline none & none & none & none & raining and cold \\
\hline none & none & none & none & cloudy and cold \\
\hline triace & trace & trace & trace & bright and cold \\
\hline trace & trace & trace & trace & bright and warm \\
\hline .014 & & .014 & .0056 & bright and warm \\
\hline
\end{tabular}

Nitrogen as Nitrates in $\mathrm{B}^{*}$

$\begin{array}{rlllll}3 & \text { none } & \text { none } & \text { none } & \text { none } & \text { raining and cold } \\ 6 & \text { none } & \text { none } & \text { none } & \text { none } & \text { cloudy and cold } \\ 9 & \text { trace } & \text { trace } & \text { trace } & \text { trace } & \text { bright and cold } \\ 12 & \text { trace } & \text { taree } & \text { trace } & \text { trace } & \text { bright and warm } \\ 15 & .014 & & .014 & .0056 & \text { bright and warm }\end{array}$

Experiment (2)

Nitrogen as Nitrites in $\mathbb{A}$

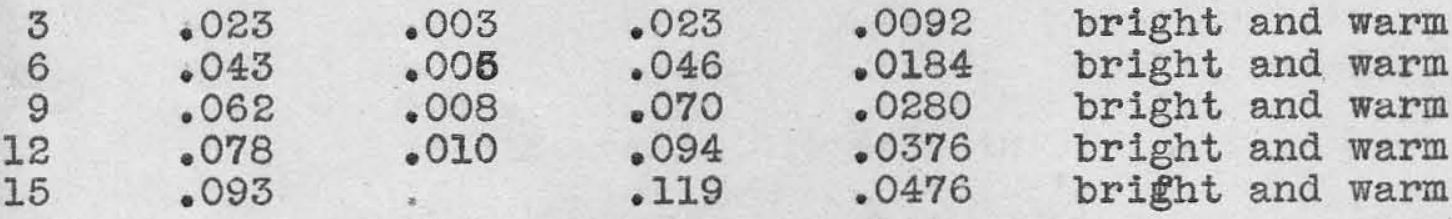

Nitrogen as Nitrites in $\mathbb{A}^{*}$

$\begin{array}{llll}.003 & .023 & .0092 & \text { bright and warm } \\ .005 & .045 & .0180 & \text { bright and warm } \\ .008 & .063 & .0284 & \text { bright and warm } \\ .010 & .095 & .0370 & \text { bright and warm } \\ & .0120 & .0480 & \text { bright and warm }\end{array}$

Nitrogen as nitrites in $B$

\begin{tabular}{rlllll}
3 & .032 & .004 & .032 & .0128 & bright and warm \\
6 & .058 & .007 & .062 & .0248 & bright and warm \\
9 & .078 & .010 & .090 & .0360 & bright and warm \\
12 & .095 & .012 & .116 & .0456 & bright and warm \\
15 & .108 & .058 & .141 & .0564 & bright and warm \\
& \multicolumn{7}{c}{ Nitrogen as Nitrites in $\mathrm{B}^{\prime}$} \\
3 & .032 & .004 & .032 & .0128 & bright and warm \\
6 & .058 & .007 & .062 & .0248 & bright and warm \\
9 & .078 & .010 & .089 & .0356 & bright and warm \\
12 & .095 & .012 & .116 & .0456 & bright and warm \\
15 & .107 & .012 & .140 & 00568 & bright and warm
\end{tabular}


Nitrogen as Nitrates in $\mathbf{A}$

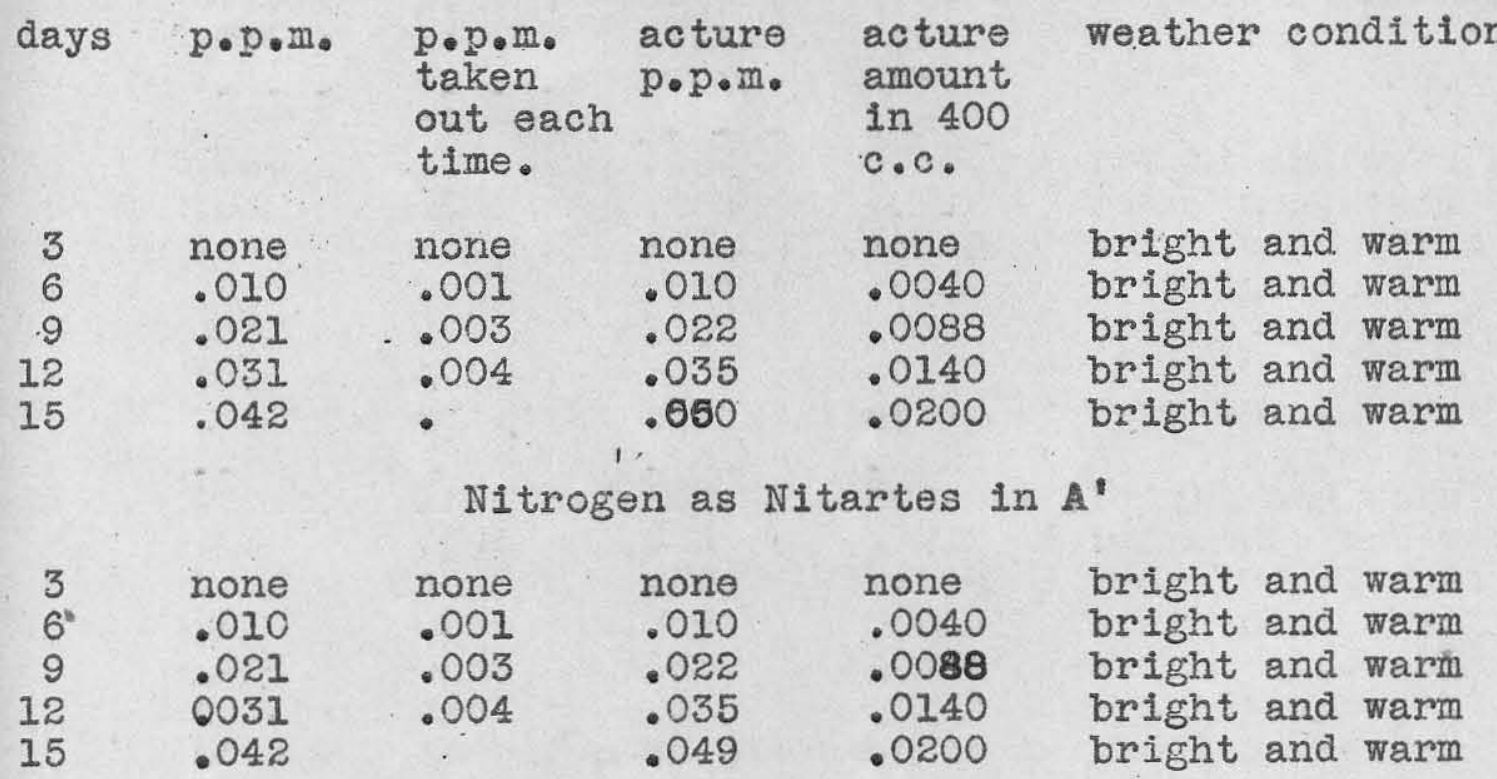

Nitrogen as Nitrates in $B$

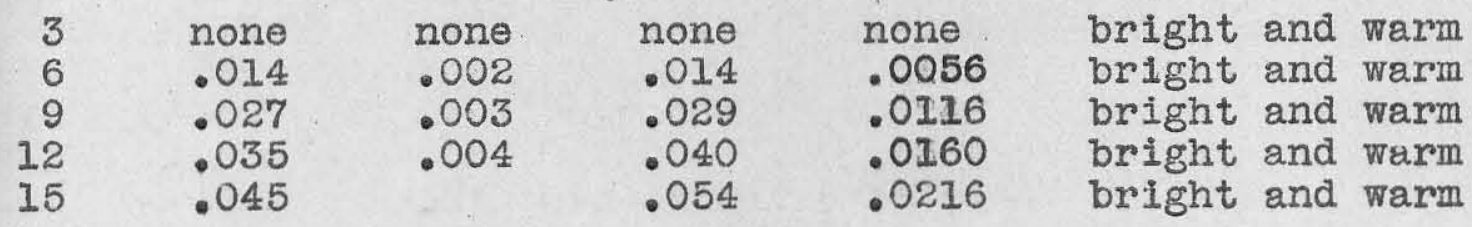

Nitrogen as Nitrates in $B^{\prime}$

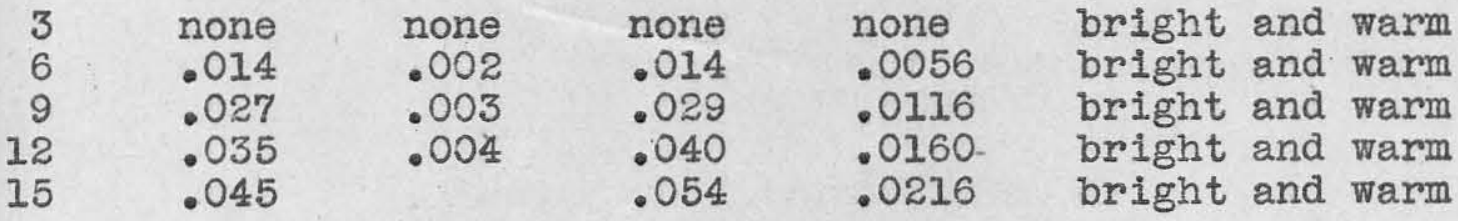

Experiment (3)

Nitrogen as Nitrites in $A$

$\begin{array}{rr}3 & .025 \\ 6 & .035 \\ 9 & .038 \\ 12 & .035 \\ 15 & .050\end{array}$

$\begin{array}{llll}.003 & .025 & .0100 & \text { bright and warm } \\ .004 & .038 & .0152 & \text { rain once, warm } \\ .005 & .045 & .0180 & \text { rain twice, cold } \\ .004 & .047 & .0188 & \text { rain and cold } \\ & .066 & .0264 & \text { bright and warm }\end{array}$

Nitrogen as Nitrites in $\mathbf{A}^{*}$

$\begin{array}{rr}3 & .025 \\ 6 & .035 \\ 9 & .037 \\ 12 & : 834 \\ 15 & .049\end{array}$

$\begin{array}{lll}.003 & .025 & .0100 \\ .004 & .038 & .0152 \\ .085 & : 844 & : 8776 \\ .084 & : 046 & .0184\end{array}$

bright and warm rain once, warm rain twicesscold bright and warm 
(23)

Nitrogen as Nitrites in B

$\begin{array}{clllll}\text { days } & \text { p.p.m. } & \begin{array}{l}\text { p.p.m. } \\ \text { taken } \\ \text { out each } \\ \text { time }\end{array} & \begin{array}{l}\text { acture } \\ \text { p.p.m. }\end{array} & \begin{array}{l}\text { acture } \\ \text { amount } \\ \text { in } 400\end{array} & \text { weather conditions } \\ \text { c.c. } & \\ 3 & .034 & .004 & .034 & .0136 & \text { bright and warm } \\ 6 & .049 & .006 & .053 & .0212 & \text { rain once, warm } \\ 9 & .052 & .006 & .062 & .0248 & \text { rain twice, cald } \\ 12 & .048 & .006 & .064 & .0256 & \text { rain and cold } \\ 15 & .063 & & .085 & .0340 & \text { bright and warm }\end{array}$

Nitrogen as Nitrites in $B^{*}$

$\begin{array}{llll}.004 & .034 & .0136 & \text { bright and warm } \\ .006 & .053 & .0212 & \text { rain once and warm } \\ .006 & .062 & .0248 & \text { rain twice, cold } \\ .006 & .064 & .0256 & \text { rain cold } \\ & .085 & .0340 & \text { bright and warm }\end{array}$

Nitrogen as Nitrates in $\mathbb{A}$

$\begin{array}{rl}3 & .010 \\ 6 & .012 \\ 9 & .012 \\ 12 & ? \\ 15 & .021\end{array}$

$$
\begin{gathered}
.010 \\
.013 \\
.014 \\
\text { ? } \\
.024
\end{gathered}
$$

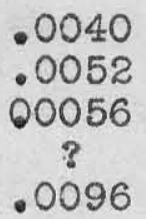

bright and warm rain once and warm rain twice, cold rain cold bright and warm

Nitrogen as Nitrates in $\mathbb{A}^{\prime}$

$\begin{array}{cc}3 & .010 \\ 6 & .012 \\ 9 & .011 \\ 12 & ? \\ 15 & .021\end{array}$

$\begin{array}{ccc}.001 & .010 & .0040 \\ .001 & .013 & .0052 \\ .001 & .013 & 00052 \\ ? & .024 & .0096\end{array}$

bright and warm rain once and warm rain twice, cold rain and cold bright and warm

Nitrogen as Nitrates in $B$

$\begin{array}{cc}3 & .010 \\ 6 & .014 \\ 9 & .013 \\ 12 & ? \\ 15 & .023\end{array}$
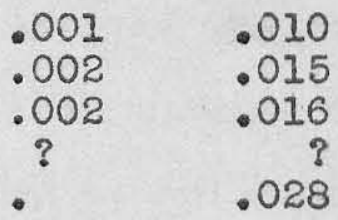
.0040 .0060 .0064 ? .0096
bright and warm rain once and warm rain twice, cold rain and cold. bright and warm

Nitrogen as Nitrates in $B^{\prime}$

$\begin{array}{rc}3 & .010 \\ 6 & .014 \\ 9 & .013 \\ 12 & ? \\ 15 & .023\end{array}$

bright and warm rain once and warm rain twice, cold rain and cold bright and warm 
$n$ The numbers in the table show distinctly that both nitrites and nitrates of air are absorbed by pure water. The alkalinity present in the water seems to help it to absorb these substances more quickIy than when pure. After 15 days the waters seem to be dirty enough to demand the use of a new set. Of the three sets of experiments the

two of them were ferformed in bad weather. The average nitrogen absorbed by water in the forms of nitrites and nitrates is . 1.5 part part per million.

(4) Discussion of Results:

A careful study of the preceding results, obtained from the three kinds of experiments convinces me that the atmosphere must be of the sources contributing to the fresh waters both nitrites and nitrates. By comparing the figures I find out that the amounts of nitrites and nitrates vary according to the temperature, or in other words these two substances are carried here by winds from the region where thunder storms frequently occur. It appears that whenever a current of warm air comes to visit us from the South (Thunder storm regiom the atmosphere contains more nitrates and nitrites. Consequently I can draw the conclusion that the atmosphere toward the equator contains much more of these two substances than that from the North. My experiments were performed in the months of November, February, March and April, and the average of the results is .15 part per million. I had in the small bottle two hundred $c . c$. of water, and it, therefore, in every one hundred cubic meters of air there are three grams of nitrogen in the forms of nitrites and nitrates. If this average is used to measure the atmosphere 
there are 8.6 tons of nitrogen in these two forms of compounds in every cubic mile of air.

The figures I obtained from the analysis of rain waters do not permit me to calculate the amount of nitrites and nitrates per acre in a year, for I did not observe the amount rain we had during the season. Howver it is sufficient to indicate the presence of these two substances in the rains, and consequently I can use these figure to prove that the atmosphere is one of the sources from wich.both nitrites and nitrates are produced.

The numbers I obtained from my experiment (3) tell us that water in free contact with the atmosphere does absorb nitrites and nitrates from air. The average amount of these two substances absorb ed by water in the little pans whose diameters are 9.5 inches each within the limit of two weeks is .128 part per million. There are .128 p.p.m. or . $0504 \mathrm{~g}$ 52 weeks in ayear. If we use the average value to measure the wain a year

ter surface absorption, we would have about two grams of nitrogen in the forms of these two compounds absorbed gx from the air by water in every acre of aqueous surface. I think it is not altogether improbable that the ground or meadows wet with dew are capable of absorbing nitrites and nitrates from the atmosphere.

In regard to the manner in which the atmosphere acquires its own nitrites and nitrates, I think we have the well accepted theory which assumes that in every thunder storm sporks of electricity combine the oxygen and nitrogen in the air into these nitrogen oxides. If the formation of nitrogen oxides depends ultimately on sporks, we would have to assume that gas diffusion and winds carry 
to our atmosphere, in the Winter, nitrites and nitrates that are produced by the thunder storms in the South. However we are sure that we do have difference in potential in our atmosphere as we are told in Ganot's physics, page' 1157. Both Lord Kelvin and Dr. G. C. Simpson investigated the same subject and they both came to the conclue sion that there are various difference of potential in the air from morning to evening. We may not be able to detect any spork in the atmosphere, but it is not inconceivable that some nitrites could be generated by such quiescent current. The numbers I obtained in $t$ the experiment (2) indicate some sort of local force which causes the union of nitrogen and oxygen to form these two compounds, for after six day's consecutive raining I still found a trace of nitrites in the rain water. Dr. Willard states that nitrites in the atmosphere are produced as the result of oxidation of ammonia.

We know that the nitrogen compounds are very essential to the tissues of both animal and vegetable organisms. With the exception of some kinds of microbes both plants and animals are incapable of absorbing nitrogen from the air to form nitrogendus compounds that are so essential to their existance, and in combustion both plant and animal remains liberates free nitrogen, Therefore in every year there is a tremendous amount of nitrogen liberated from its compounds by combustion, and in the same year vegetation and animals grow as usual. In addition to the amount of nitrogenous compounds produced by thunder storms, I think the local generation of such compounds by the difference in potential in the atmosphere should be counted as a possible source for making up the annual loss of ni- 
(27)

trogen available for plant food. From the preceding results and $d$ discussion, I predict that fresh waters in hot places contain more nitrogenous compounds than those in the cold regions.

It will also be noted that all my experiments were performed in the city the atmosphere contains a great deal of smoke.

ale. y. $\mathrm{Lu}$ 